\title{
Preventing Bacterial Contamination and Proliferation During the Harvest, Storage, and Feeding of Fresh Bovine Colostrum
}

\author{
S. Stewart, ${ }^{1}$ S. Godden, ${ }^{1}$ R. Bey, ${ }^{2}$ P. Rapnicki, ${ }^{1}$ J. Fetrow,${ }^{1}$ R. Farnsworth, ${ }^{1}$ \\ M. Scanlon, ${ }^{1}$ Y. Arnold, ${ }^{1}$ L. Clow, ${ }^{1}$ K. Mueller, ${ }^{1}$ and C. Ferrouillet ${ }^{1}$ \\ ${ }^{1}$ Department of Veterinary Population Medicine, and \\ ${ }^{2}$ Department of Veterinary and Biomedical Sciences, University of Minnesota, St. Paul 55108
}

\begin{abstract}
The objectives of this study were to identify control points for bacterial contamination of bovine colostrum during the harvesting and feeding processes, and to describe the effects of refrigeration and use of potassium sorbate preservative on bacteria counts in stored fresh colostrum. For objective 1, first-milking colostrum samples were collected aseptically directly from the mammary glands of 39 cows, from the milking bucket, and from the esophageal feeder tube. For objective 2, 15-mL aliquots of colostrum were collected from the milking bucket and allocated to 1 of 4 treatment groups: 1) refrigeration, 2) ambient temperature, 3 ) refrigeration with potassium sorbate preservative, and 4) ambient temperature with potassium sorbate preservative. Subsamples from each treatment group were collected after 24,48 , and $96 \mathrm{~h}$ of storage. All samples underwent bacteriological culture for total plate count and coliform count. Bacteria counts were generally low or zero in colostrum collected directly from the gland [mean (SD) $\log _{10} \mathrm{cfu} / \mathrm{mL}_{\text {udder }}=1.44$ (1.45)]. However, significant bacterial contamination occurred during the harvest process [mean (SD) $\log _{10} \mathrm{cfu} / \mathrm{mL}_{\text {bucket }}=4.99$ (1.95)]. No additional bacterial contamination occurred between the bucket and the esophageal feeder tube. Storing colostrum at warm ambient temperatures resulted in the most rapid increase in bacteria counts, followed by intermediate rates of growth in nonpreserved refrigerated samples or preserved samples stored at ambient temperature. The most effective treatment studied was the use of potassium sorbate preservative in refrigerated samples, for which total plate count and total coliform counts dropped significantly and then remained constant during the 96-h storage period.
\end{abstract}

(Key words: colostrum, bacterial contamination, storage, preservative)

Received September 13, 2004.

Accepted March 10, 2005.

Corresponding author: Sandra Godden; e-mail: godde002@umn.
Abbreviation key: $\mathbf{T C C}=$ total coliform count, $\mathbf{T P C}=$ total plate count.

\section{INTRODUCTION}

The 1993, 1996, and 2002 National Animal Health Monitoring System dairy studies report that an unacceptably high mortality rate (8.4 to $10.7 \%$ ) exists among preweaned heifers on US dairy farms (NAHMS, 1993, 1996, 2002). Failure of passive transfer, resulting from suboptimal colostrum management, has been identified as a key risk factor contributing to these high mortality rates (Wells et al., 1996). Experts have identified that the hallmarks of a successful colostrum management program consider the quality of the colostrum fed (Ig concentration), the quantity provided at first feeding, and how quickly the first feeding is offered (Davis and Drackley, 1996). Successive National Animal Health Monitoring System dairy studies over the past decade have reported a steady slow increase in the adoption of recommended colostrum management practices, such as hand-feeding the calf, and feeding larger volumes at first feeding (NAHMS, 1996, 2002). However, the continuation of unacceptably high preweaning mortality rates in dairy heifers indicates that there is still much room for improvement in our colostrum and calf management programs. Colostrum cleanliness may represent one important area of opportunity.

Although colostral immune factors are essential for calf health, bacterial contamination of colostrum may negate some of these benefits. Bacterial pathogens that may be transmitted in colostrum and milk, either by direct shedding from the mammary gland or from postharvest contamination, include Mycobacterium avium spp. paratuberculosis, Salmonella spp., Mycoplasma spp., Listeria monocytogenes, Campylobacter spp., Mycobacterium bovis, and Escherichia coli (Lovett et al., 1983; Farber et al., 1988; McEwen et al., 1988; Clarke et al., 1989; Giles et al., 1989; Streeter et al., 1995; Grant et al., 1996; Steele et al., 1997; Walz et al., 1997). These infectious agents may act directly to cause diseases such as enteritis or septicemia. It has also been suggested that the presence of bacteria in the small 
intestine at the time of colostrum administration could interfere with systemic absorption of Ig molecules. Possible mechanisms for this effect could include competition between microbes and Ig molecules for common receptors on the intestinal epithelial cell, or physical binding of colostral Ig by microbes within the intestinal lumen, thus decreasing the availability of transportable Ig (James and Polan, 1978; James et al., 1981; Staley and Bush, 1985). Although field studies describing the significance of this effect in calves are extremely limited, one recent study reported that a negative association exists between bacteria counts in colostrum and Ig absorption (Poulsen et al., 2002). This same study reported that $82 \%$ of colostrum samples collected exceeded the industry standard of $100,000 \mathrm{cfu} / \mathrm{mL}$ total plate count (TPC). Although actual numbers were not published, the study reported that total bacterial and fecal coliform counts in colostrum were positively correlated with abnormal fecal consistency (Poulsen et al., 2002).

Clearly, more field studies are necessary to investigate the relationship between bacterial counts in colostrum and both the efficiency of absorption of colostral antibodies and calf health. However, if a negative relationship does exist, then we must develop and validate practical recommendations on how to prevent contamination of colostrum, either during the harvest or storage processes. The first objective of this study was to describe critical control points for bacterial contamination in the colostrum collection and feeding processes. The second objective was to describe the effect of refrigeration (vs. ambient temperature) and the use of potassium sorbate preservative on bacteria counts in fresh bovine colostrum stored for up to $96 \mathrm{~h}$.

\section{MATERIALS AND METHODS}

\section{Housing and Management of Study Animals}

Research activities were completed in August, 2003, in a commercial 400-cow sand-bedded, freestall facility that houses transition cows from entry into the closeup period ( $\sim 45 \mathrm{~d}$ before calving), through the calving process, and until approximately 10 to $14 \mathrm{~d}$ in milk, after which time the lactating cows are returned to 1 of 2 large commercial dairy operations to complete their lactation. First-milking colostrum is routinely collected into a floor bucket within $1 \mathrm{~h}$ of calving. Newborn calves are fed $3.8 \mathrm{~L}$ of the dam's first-milking colostrum, using an esophageal tube feeder, usually within 15 to $30 \mathrm{~min}$ of milking the dam.

The standard procedure for sanitation of all equipment used in collection and feeding of the first colostrum (including the floor bucket, milking equipment, and esophageal tubes) was as follows: 1) disassembly of all equipment, 2) rinsing with lukewarm water to remove all visual soil and milk, 3) placing in hot water containing detergent, 4) scrubbing all exterior and interior surfaces with a brush, 5) rinsing with hot water containing acid sanitizer, and 6) allowing all equipment to drain completely and air dry.

\section{Sample Collection and Storage Procedures}

To address the first objective, 3 distinct samples of first-milking colostrum were obtained from each of 41 just-fresh cows. Following routine udder-preparation, which included fore-stripping and predipping with a $0.5 \%$ iodine-based teat dip, and drying the teat ends with a clean cloth towel, all teat ends were scrubbed with an alcohol-soaked gauze pad. The first sample was then aseptically stripped directly into a sterile $20-\mathrm{mL}$ plastic sampling vial with approximately equal amounts of milk collected from the 4 quarters, and then frozen at $-20^{\circ} \mathrm{C}$. The milking unit was attached and the cow milked immediately after collecting this first sample (group 1 in Table 1). The second sample of colostrum was aseptically collected from the floor bucket into a sterile $240-\mathrm{mL}$ plastic sampling vial within 15 to 20 min of milking the cow (group 3 in Table 1). A $15-\mathrm{mL}$ aliquot was taken from the $240-\mathrm{mL}$ sample and frozen. This $240-\mathrm{mL}$ sample was also the source for aliquots described in the next paragraph for objective 2. Finally, a third sample was aseptically collected directly from the esophageal feeder tube into a sterile 20 $\mathrm{mL}$ plastic sampling vial, within 15 to 30 min of milking the cow (group 2 in Table 1), and also frozen.

To address the second objective, a 240 -mL first-milking colostrum sample was aseptically collected directly from the floor bucket within 15 to 30 min of milking the cow. As described in the previous paragraph, a 15$\mathrm{mL}$ aliquot from the $240 \mathrm{~mL}$ was taken and immediately frozen for use under objective 1 . The remaining large volume was then divided into 12 identical aliquots of approximately $15 \mathrm{~mL}$ each. These aliquots were then randomly allocated to 1 of 4 different treatment groups:

Group 4. Samples 4a, 4b, 4c: Stored in refrigerator $\left(4^{\circ} \mathrm{C}\right)$.

Group 5. Samples 5a, 5b, 5c: Stored at ambient temperature.

Group 6. Samples 6a, 6b, 6c: Potassium sorbate $(0.5 \%$ $\mathrm{wt} / \mathrm{vol})$ and refrigerated $\left(4^{\circ} \mathrm{C}\right)$.

Group 7. Samples 7a, 7b, 7c: Potassium sorbate $(0.5 \%$ $\mathrm{wt} / \mathrm{vol}$ ) and stored at ambient temperature.

For samples in groups 6 and 7, a 50\% potassium sorbate solution was mixed with colostrum immediately after sample collection to create a $0.5 \%$ solution (wt/ 
vol). For all 4 treatment groups, subsamples a, b, and c were frozen after 24,48 , and $96 \mathrm{~h}$ of storage, respectively. Local weather service data reported that the average daily temperature for the study period was $23^{\circ} \mathrm{C}$ (range: 19.6 to $26.8^{\circ} \mathrm{C}$ ).

\section{Laboratory Analyses}

All frozen colostrum samples were submitted to the Laboratory for Udder Health, University of Minnesota (St. Paul, MN) where they underwent microbiological culture procedures to determine TPC, total coliform count (TCC), and testing for sample $\mathrm{pH}$. After the colostrum samples were thawed and thoroughly mixed, serial 10-fold dilutions of the colostrum were made in sterile brain-heart infusion broth. Two hundred microliters of colostrum from each dilution was then pipetted onto MacConkey agar and spread over the entire surface. The plates were incubated at $37^{\circ} \mathrm{C}$ for $24 \mathrm{~h}$, and all pink colonies (lactose fermenters) were counted. Colonies were confirmed as coliforms using the API $20 \mathrm{E}$ coliform identification test (bioMerieux, Inc., Hazelwood, MO). The same serial 10-fold dilutions of colostrum in brain-heart infusion broth were used for TPC determination. Two hundred microliters of each dilution was placed on the surface of plate count agar plates and spread as above. The plates were incubated at $32^{\circ} \mathrm{C}$ for $48 \mathrm{~h}$ and all colonies counted. An Orion $\mathrm{pH}$ meter (Orion Research, Cambridge, MA) was used to perform $\mathrm{pH}$ testing of colostrum samples.

\section{Statistical Analyses}

Final analysis was completed for 39 of the 41 cows sampled. All samples from 2 cows were omitted from analysis because there were significantly higher coliform counts in samples collected directly from the udder $\left(1.0 \times 10^{7} \mathrm{cfu} / \mathrm{mL}\right)$ than in subsequent samples collected from the milking bucket $\left(2.6 \times 10^{6} \mathrm{cfu} / \mathrm{mL}\right)$, leading to concerns about gross contamination of the first sample during or after the sample collection process.

\section{Critical Contamination Points During Colostrum Harvest and Feeding}

Descriptive statistics were produced to describing the mean, SD, and range of the $\log _{10}$ transformed values for the TPC and TCC in the colostrum samples from the udder, the floor bucket, and the esophageal tube feeder (Table 1). An ANOVA was used (Proc Mixed; SAS Institute, 2000) to describe the relationship between the explanatory variable of interest, sample source (udder, bucket, or esophageal feeder) and the 2 dependent variables of interest, $\log _{10}(\mathrm{TPC}, \mathrm{cfu} / \mathrm{mL})$ and $\log _{10}(\mathrm{TCC}, \mathrm{cfu} / \mathrm{mL})$. A variable describing "cow" was included as a random effect in the model to control for multiple samples clustered within cow. Statistical significance was declared at $P<0.05$.

\section{Effect of Refrigeration and Preservative on Bacterial Counts in Stored Fresh Colostrum}

Descriptive statistics were produced to describe the mean, SD, and range of the $\log _{10}$ transformed values for the TPC and TCC, plus mean, SD, and range of the sample $\mathrm{pH}$ measures, for the 4 treatment groups after 24, 48, and $96 \mathrm{~h}$ of storage (Tables 1 and 2). Multivariate ANOVA was then used (Proc Mixed; SAS Institute, 2000) to describe the relationship between the explanatory variable of interest, storage treatment group ( $4=$ refrigeration, $5=$ ambient temperature, $6=$ refrigeration plus preservative, $7=$ ambient temperature plus preservative), and the 3 dependent variables of interest: $\log _{10}$ TPC (cfu/mL), $\log _{10}$ TCC (cfu/mL), and sample $\mathrm{pH}$, and controlling for sampling time (24, 48, and $96 \mathrm{~h}$ ) as a covariate in the model. The presence of an interaction between treatment and time was investigated. A variable describing "cow" was included as a random effect in these models to control for multiple samples clustered within each cow. Statistical significance was declared at $P<0.05$.

\section{RESULTS}

\section{Critical Contamination Points During Colostrum Harvest and Feeding}

Bacteria counts were very low in samples collected directly from the udder, with $100 \%$ of samples collected meeting the goal for the maximum TPC to be fed to calves at $<100,000 \mathrm{cfu} / \mathrm{mL}$. However, there was a significant increase in bacteria counts in samples collected directly from the floor bucket (Table 1, Figure 1). There was no difference in TPC or TCC between samples collected from the floor bucket vs. the esophageal feeder tube $(P>0.05)$. Only $64 \%$ (23/39) of samples collected from the esophageal feeder tube had a TPC less than $100,000 \mathrm{cfu} / \mathrm{mL}$.

\section{Effect of Refrigeration and Preservative on Bacterial Counts in Stored Fresh Colostrum}

Multivariate analysis indicated the presence of a significant interaction between storage method (treatment groups $4,5,6$, or 7 ) and storage period (24, 48, or $96 \mathrm{~h}$ ). Thus, the data was subsequently stratified by storage period and reanalyzed to describe the effect of treatment. When examining TPC in untreated samples stored at ambient temperature (group 5), bacteria 
Table 1. Description of bacterial counts in colostrum samples by treatment group and storage conditions.

\begin{tabular}{|c|c|c|c|c|c|c|c|}
\hline \multirow{2}{*}{$\begin{array}{l}\text { Treatment } \\
\text { group }\end{array}$} & \multirow[b]{2}{*}{ Source } & \multicolumn{3}{|c|}{$\begin{array}{l}\text { Total plate count, } \\
\log _{10}(\mathrm{cfu} / \mathrm{mL})\end{array}$} & \multicolumn{3}{|c|}{$\begin{array}{c}\text { Total coliform count, } \\
\log _{10}(\mathrm{cfu} / \mathrm{mL})\end{array}$} \\
\hline & & Mean & $\mathrm{SD}$ & Range & Mean & $\mathrm{SD}$ & Range \\
\hline 1 & Udder & 1.44 & 1.45 & $0-4.78$ & 0.90 & 1.20 & $0-4.42$ \\
\hline 2 & Esophageal feeding tube & 4.66 & 1.89 & $2.0-8.75$ & 4.45 & 2.03 & $0.70-8.56$ \\
\hline 3 & Floor bucket & 4.99 & 1.95 & $2.0-9.25$ & 4.71 & 2.17 & $0-9.16$ \\
\hline $4 \mathrm{a}$ & Refrigerated, $24 \mathrm{~h}$ & 5.75 & 1.93 & $2.0-9.01$ & 5.50 & 2.06 & $2.18-8.91$ \\
\hline $4 \mathrm{~b}$ & Refrigerated, $48 \mathrm{~h}$ & 6.03 & 1.76 & $2.70-9.36$ & 5.55 & 2.02 & $0-8.94$ \\
\hline $4 \mathrm{c}$ & Refrigerated, $96 \mathrm{~h}$ & 6.17 & 1.80 & $3.0-9.57$ & 5.91 & 1.80 & $2.95-9.01$ \\
\hline $5 \mathrm{a}$ & Ambient temperature, $24 \mathrm{~h}$ & 7.26 & 0.80 & $6.09-9.19$ & 6.39 & 1.30 & $3.34-9.10$ \\
\hline $5 \mathrm{~b}$ & Ambient temperature, $48 \mathrm{~h}$ & 6.62 & 0.83 & $4.54-8.62$ & 4.96 & 1.84 & $0-8.60$ \\
\hline $5 \mathrm{c}$ & Ambient temperature, $96 \mathrm{~h}$ & 6.63 & 0.86 & $4.05-8.26$ & 4.48 & 1.80 & $0-7.89$ \\
\hline $6 \mathrm{a}$ & Refrigerated + preservative, $24 \mathrm{~h}$ & 3.60 & 1.63 & $0-8.24$ & 3.14 & 1.72 & $0-7.78$ \\
\hline $6 \mathrm{~b}$ & Refrigerated + preservative, $48 \mathrm{~h}$ & 3.64 & 1.45 & $1.40-7.67$ & 3.39 & 1.64 & $0-7.71$ \\
\hline $6 \mathrm{c}$ & Refrigerated + preservative, $96 \mathrm{~h}$ & 3.55 & 1.64 & $0-7.59$ & 3.39 & 1.77 & $0-7.72$ \\
\hline $7 \mathrm{a}$ & Ambient + preservative, $24 \mathrm{~h}$ & 5.43 & 1.35 & $3.08-9.25$ & 4.71 & 1.11 & $1.85-6.70$ \\
\hline $7 \mathrm{~b}$ & Ambient + preservative, $24 \mathrm{~h}$ & 6.48 & 0.80 & $4.60-7.88$ & 5.02 & 0.98 & $1.70-6.55$ \\
\hline $7 \mathrm{c}$ & Ambient + preservative, $24 \mathrm{~h}$ & 6.54 & 0.92 & $4.06-8.84$ & 2.87 & 1.13 & $0-5.20$ \\
\hline
\end{tabular}

counts increased most rapidly during the first $24 \mathrm{~h}$, followed by a slight decrease and then leveling off by $96 \mathrm{~h}$ (Table 1, Figure 2). Moderate and similar increases in bacteria counts over the entire 96 -h period were observed for untreated samples stored using refrigeration (group 4), and for preserved samples stored at ambient temperature (group 7). After $96 \mathrm{~h}$ of storage, there was no difference in TPC among treatment groups 4,5 , and 7 (Figure 2). By contrast, the TPC in samples stored using potassium sorbate preservative and refrigeration had dropped by $24 \mathrm{~h}$ and stayed low and constant over the duration of the 96-h study period (group 6). The TPC in this treatment group was lower than in any other treatment group at 24,48 , and $96 \mathrm{~h}$ of storage (Table 1, Figure 2).

When examining the TCC in untreated samples stored at ambient temperature, counts increased most rapidly during the first $24 \mathrm{~h}$ followed by a significant drop after 48 and $96 \mathrm{~h}$ (group 5) (Table 1, Figure 3). Total coliform counts rose moderately during the first $24 \mathrm{~h}$ in untreated refrigerated samples and continued to rise very slowly until $96 \mathrm{~h}$ (group 4). Total coliform counts in preserved samples stored at ambient temperature remained relatively unchanged during the first $48 \mathrm{~h}$, but then dropped by $96 \mathrm{~h}$ (group 7). Total coliform counts in preserved refrigerated samples (group 6) dropped significantly by $24 \mathrm{~h}$ and stayed low and constant over the duration of the 96-h study period (group 6). Coliform counts in the latter treatment group were lower than for any other treatment group at 24, 48, and $96 \mathrm{~h}$ of storage, with the exception of samples in treatment group 7 at $96 \mathrm{~h}$ (Table 1, Figure 3).

The mean (SD) $\mathrm{pH}$ in the bucket sample $(0 \mathrm{~h})$ was 5.59 (0.39) (Table 2, Figure 4). The pH in samples stored using potassium sorbate preservative and refrigeration rose slightly after $24 \mathrm{~h}$ and then remained constant (group 6), whereas the $\mathrm{pH}$ levels remained relatively unchanged in untreated refrigerated samples throughout the entire 96-h study period (group 4) (Table 2, Figure 4). By contrast, sample $\mathrm{pH}$ fell significantly in any samples stored at ambient temperature; after 24 $\mathrm{h}$ of storage for untreated samples stored at ambient temperature (group 5), and after $48 \mathrm{~h}$ of storage for preserved samples stored at ambient temperature (group 7) (Table 2, Figure 4).

\section{DISCUSSION}

\section{Critical Contamination Points During Colostrum Harvest and Feeding}

If feeding clean colostrum is an important factor influencing calf health, then the first step in achieving this goal must be to prevent contamination during the harvest and feeding processes. Although this study was limited to evaluating the practices of only one farm, it is the first, to our knowledge, to identify the critical control points for bacterial contamination during the colostrum harvest and feeding processes, and to quantify the degree of contamination occurring. The study demonstrated that most colostrum samples collected aseptically directly from the gland have extremely low numbers of bacteria present, and frequently no growth. However, the results showed a significant increase in TPC and TCC after harvesting of that colostrum into a milking bucket. This identifies the harvesting process as a significant control point for contamination of colostrum. Possible sources of such contamination could include the teat skin, milking cup liners, hoses, or floor bucket. Such results indicated that an improvement in the udder preparation routine or improvement in the sanitation procedure for the milking equipment might 


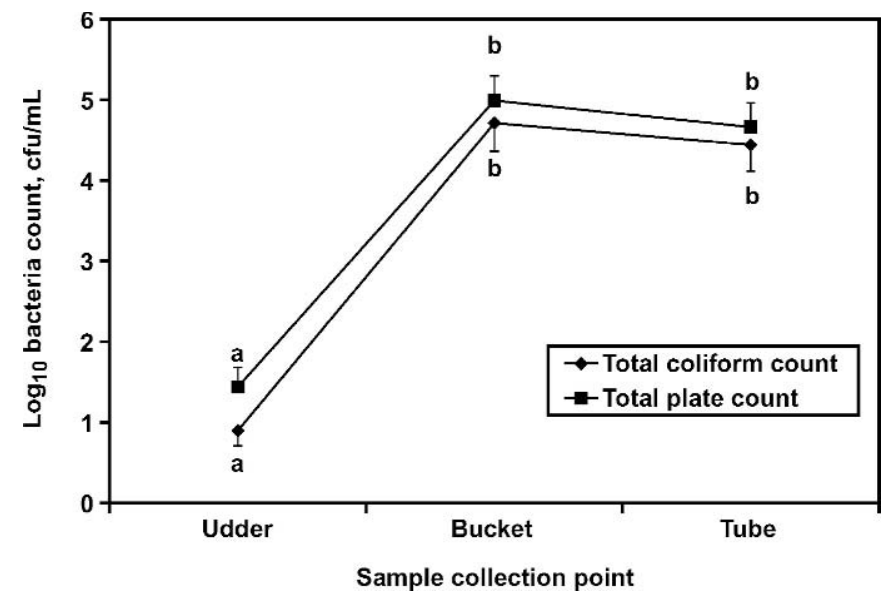

Figure 1. Mean $\log _{10}$ total plate count and mean $\log _{10}$ total coliform count for colostrum samples collected from the udder, the milking bucket, and the esophageal feeder tube. ${ }^{\mathrm{a}, \mathrm{b}}$ Different subscripts differ within bacteria type group, $P<0.05$.

be required on the study farm. The current study did not show additional contamination occurring during the feeding process (e.g., from the esophageal feeder tube), although it is possible that this could serve as an additional source of contamination on dairy farms if feeding instruments are not properly sanitized between uses. The information from this study has provided a first step in identifying the important control points that researchers and producers should address. Further research is needed to describe the amount and variation in the degree of bacterial contamination that occurs on a large sample of commercial dairy farms, to establish realistic and scientifically based targets for maximum levels of bacterial contamination occurring during the

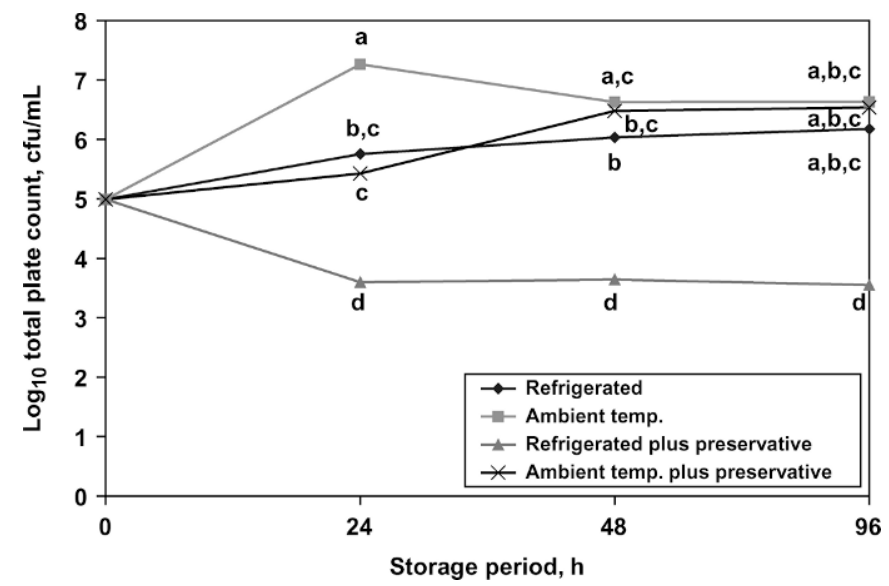

Figure 2. Effect of storage method over time on mean $\log _{10}$ total plate count in fresh bovine colostrum. ${ }^{\mathrm{a}, \mathrm{b}, \mathrm{c}, \mathrm{d}}$ Different subscripts differ within given storage period, $P<0.05$. 


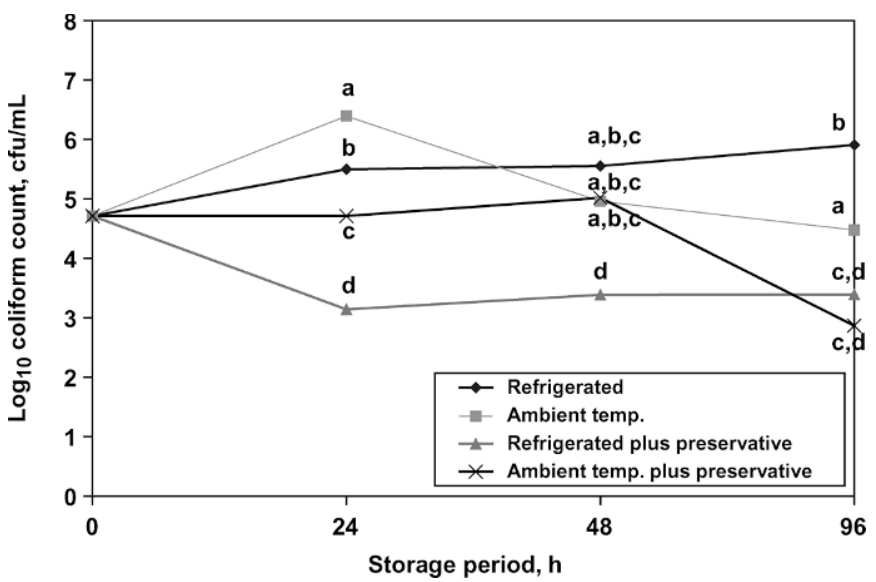

Figure 3. Effect of storage method over time on mean $\log _{10}$ total coliform count in fresh bovine colostrum. ${ }^{\mathrm{a}, \mathrm{b}, \mathrm{c}, \mathrm{d}}$ Different subscripts differ within given storage period, $P<0.05$.

harvest and feeding processes, and to develop and validate a set of best management practices that producers can implement to prevent bacterial contamination during these processes.

\section{Storage at Ambient Temperature vs. Refrigeration}

The results of the current study are comparable to previous findings in that the total microbial population in untreated colostrum stored at warm ambient temperatures multiplied rapidly early on, and then either leveled off or diminished. In a previous study of naturally fermented bovine colostrum stored at room temperature for $10 \mathrm{~d}$, the TPC was found to increase over the first $4 \mathrm{~d}$ of storage (Sukumaran and Subrahmanyam,

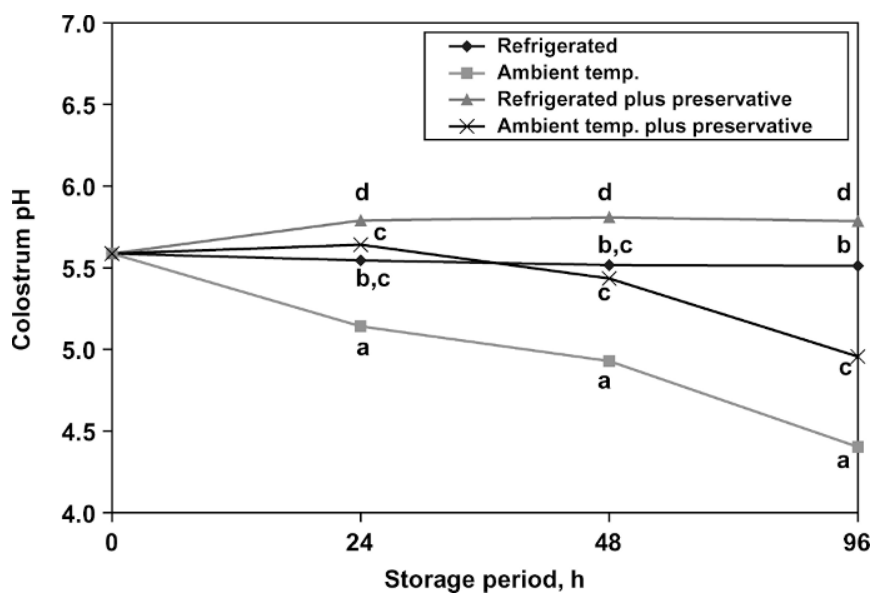

Figure 4. Effect of storage method over time on $\mathrm{pH}$ in fresh bovine colostrum. ${ }^{a, b, c, d}$ Different subscripts differ within given storage period, $P<0.05$.
1980). Palmer and Mudd (1972) reported an increase in the TPC during the first $3 \mathrm{~d}$ of storage, followed by a leveling off or decrease in number.

In the current study, the TCC in the samples stored at warm ambient temperatures also rose significantly during the first $24 \mathrm{~h}$ and then declined, with concentrations at the end of the $96 \mathrm{~h}$ storage period being similar to the initial counts at time zero. This was similar to other studies that reported an initial increase in coliforms, followed by a marked decrease after 3 to $5 \mathrm{~d}$ of storage (Roy, 1964; Palmer and Mudd, 1972; Sukumaran and Subrahmanyam, 1980).

The current study showed that bacterial growth for both TPC and TCC was significantly delayed in untreated samples stored in the refrigerator (vs. warm ambient temperature). However, by 48 and $96 \mathrm{~h}$ of storage, there was no significant difference in the TPC between these 2 treatment groups. By contrast, the TCC in untreated samples stored at ambient temperature were lower after $96 \mathrm{~h}$ of storage compared with TCC in untreated samples stored in the refrigerator. These results show that refrigeration is effective at retarding pathogen growth. However, this benefit was shortlived. As such, it may be possible that producers storing untreated colostrum in the refrigerator should still strive to feed it as quickly as possible (e.g., within 1 to $2 \mathrm{~d}$ ), as compared with the 1-wk guideline commonly followed in the industry. More studies are needed to further investigate this hypothesis and its relationship to calf health.

In this study the drop in TCC observed in untreated samples stored at ambient temperature (group 5) was correlated with the significant drop in $\mathrm{pH}$ that ensued by $24 \mathrm{~h}$, due to onset of the fermentation process. It appeared that initiation of fermentation was delayed slightly, but still occurred, in preserved samples stored at ambient temperature (group 7), as evidenced by a significant drop in $\mathrm{pH}$ by $48 \mathrm{~h}$ of storage in this group of samples. Many earlier studies have reported a similar initial rapid growth period followed by a decrease in coliform bacteria counts associated with the increased acidity of fermented colostrum (Palmer and Mudd, 1972; Thompson and Marth, 1976). Some readers might interpret these results to infer that producers should intentionally allow fresh colostrum to ferment, before feeding to newborn calves, to reduce coliform exposure. However, the authors suggest that producers may want to avoid fermentation of stored fresh colostrum for the following 3 reasons: First, the current study showed that, even after fermentation of untreated colostrum stored at ambient temperature for $96 \mathrm{~h}$, coliform counts remained relatively high [mean $(\mathrm{SD}) \log _{10} \mathrm{TCC}_{96 \mathrm{~h}}=4.48$ (1.80) $\mathrm{cfu} / \mathrm{mL}$. Thompson and Marth (1976) also reported that coliform counts were still relatively high 
( $10^{4}$ to $10^{6} \mathrm{cfu} / \mathrm{mL}$ ) even after $21 \mathrm{~d}$ of storage. Second, it has been documented that counts of some pathogens other than coliforms may remain high (e.g., Salmonella typhimurium) or even increase (e.g., Salmonella dublin) after $5 \mathrm{~d}$ in acidic fermented bovine colostrum (Palmer and Mudd, 1974). Finally, some studies have reported that newborn calves absorbed smaller amounts of Ig from fermented colostrum than from fresh colostrum or colostrum stored by freezing (Snyder et al., 1974; Foley et al., 1978).

\section{Use of Potassium Sorbate Preservative}

In this study, treatment of colostrum with potassium sorbate preservative slowed the rate of bacterial growth and prevented or delayed the fermentation process in treated samples stored at ambient temperature (group 7). However, by far the most successful treatment tested was treatment with potassium sorbate preservative combined with refrigeration. Total coliform counts and TPC in these samples were significantly reduced by 24 $\mathrm{h}$, and stayed stable throughout the $96-\mathrm{h}$ study period. Sample pH measures were highest, and remained constant over $96 \mathrm{~h}$, in these samples. These results agree with several previous studies reporting that chemical treatment with such additives as formaldehyde, propionic acid, potassium sorbate, sorbitol, or sodium benzoate, will retard or prevent bacterial and coliform growth in fermented colostrum (Palmer and Mudd, 1972; Muller and Smallcomb, 1977; Rindsig et al., 1977). In a comprehensive review of the literature on the longterm storage of fermented colostrum, Foley and Otterby (1978) recommended the use of chemical preservatives if fermented colostrum was to be stored at warm temperatures. However, the results of this study would suggest that there are additive benefits to combining the use of a potassium sorbate preservative with refrigeration of fresh colostrum to be stored for short periods of time (up to $96 \mathrm{~h}$ ).

\section{CONCLUSIONS}

This study demonstrated that the colostrum harvest process is a significant critical control point for bacterial contamination of first-milking colostrum. Storing untreated colostrum at warm ambient temperatures resulted in the most rapid increase in bacterial counts, followed by intermediate rates of growth in untreated samples stored using refrigeration, or samples treated with potassium sorbate preservative and stored at ambient temperature. The most effective treatment was the use of potassium sorbate preservative combined with refrigeration, in which TPC and TCC dropped significantly and then remained constant during the 96- h storage period. Future studies will be necessary to describe the relationship between bacterial counts in colostrum and subsequent calf health and to define science-based recommendations for bacteria levels in fresh colostrum fed to calves. Moreover, studies are needed to compare the effectiveness of different types and doses of preservative agents, to describe the shelf life of preserved and refrigerated fresh colostrum, and to describe the cost-benefit of using potassium sorbate preservative in stored fresh colostrum.

\section{ACKNOWLEDGMENTS}

This study was funded by the Minnesota Rapid Agricultural Response Fund. The authors would like to express their extreme appreciation to Jim Lewis, Dan Priestler, and the owners of Emerald II Dairy (the TMF) for their cooperation with the study.

\section{REFERENCES}

Clarke, R. C., S. A. McEwen, V. P. Gannon, H. Lior, and C. L. Gyles. 1989. Isolation of verocytotoxin-producing Escherichia coli from milk filters in Southwestern Ontario. Epidemiol. Infect. 102:253-260.

Davis, C. L., and J. K. Drackley. 1998. Pages 179-206 in The Development, Nutrition, and Management of the Young Calf. 1st ed. Iowa State Univ. Press, Ames, IA.

Farber, J. M., G. W. Sanders, and S. A. Malcolm. 1988. The presence of Listeria spp. in raw milk in Ontario. Can. J. Microbiol. 34:95-100.

Foley, J. A., and D. E. Otterby. 1978. Availability, storage, treatment, composition, and feeding value of surplus colostrum: A review. J. Dairy Sci. 61:1033-1060.

Foley, J. A., A. G. Hunter, and D. E. Otterby. 1978. Absorption of colostral proteins by newborn calves fed unfermented, fermented, or buffered colostrum. J. Dairy Sci. 61:1450-1456.

Giles, N., S. A. Hopper, and C. Wray. 1989. Persistence of S. typhimurium in a large dairy herd. Epidemiol. Infect. 103:235-241.

Grant, I. R., H. J. Ball, and M. T. Rowe. 1996. Thermal inactivation of several Mycobacterium spp. in milk by pasteurization. Appl. Microbiol. 22:253-256.

James, R. E., and C. E. Polan. 1978. Effect of orally administered duodenal fluid on serum proteins in neonatal calves. J. Dairy Sci. 61:1444-1449.

James, R. E., C. E. Polan, and K. A. Cummins. 1981. Influence of administered indigenous microorganisms on uptake of [I-125] $\gamma$ globulin in vivo by intestinal segments of neonatal calves. J. Dairy Sci. 64:52-61.

Lovett, J., D. W. Francis, and J. M. Hunt. 1983. Isolation of Campylobacter jejuni from raw milk. Appl. Environ. Microbiol. 46:459-462.

McEwen, S. A., W. Martin, R. C. Clarke, and S. E. Tamblyn. 1988. A prevalence survey of Salmonella in raw milk in Ontario, 198687. J. Food Prot. 51:963-965.

Muller, L. D., and J. Smallcomb. 1977. Laboratory evaluation of several chemicals for preservation of excess colostrum. J. Dairy Sci. 60:627-631.

National Animal Health Monitoring System (NAHMS). 1993. National Dairy Heifer Evaluation Project. Dairy Herd Management Practices Focusing on Preweaned Heifers. USDA-APHIS Veterinary Services. Ft. Collins, CO.

National Animal Health Monitoring System (NAHMS). 1996. Dairy 1996: National Dairy Health Evaluation Project. Dairy heifer morbidity, mortality, and health management focusing on preweaned heifers. USDA-APHIS Veterinary Services. Ft. Collins, CO. 
National Animal Health Monitoring System (NAHMS). 2002. Dairy 2002. Part 1: Reference of Dairy Health and Management in the United States. USDA-APHIS Veterinary Services. Ft. Collins, CO.

Palmer, G. H., and A. J. Mudd. 1972. A note on the growth of some microorganisms in stored bovine colostrum. J. Dairy Res. 9:227-230.

Palmer, G. H., and A. J. Mudd. 1974. The survival and possible multiplication of Salmonella dublin and Salmonella typhimurium in stored bovine colostrum. Vet. Rec. 94:129.

Poulsen, K. P., F. A. Hartmann, and S. M. McGuirk. 2002. Bacteria in colostrum: Impact on calf health. Page 773 in Proc. 20th Am. Coll. Intern. Vet. Med., Dallas, TX.

Rindsig, R. B., J. G. Janecke, and G. W. Bodoh. 1977. Influence of formaldehyde and propionic acid on composition of microflora of colostrum. J. Dairy Sci. 60:63-72.

Roy, J. H. B. 1964. The nutrition of intensively reared calves. Vet. Rec. 76:511.

SAS Institute. 2000. SAS User's Guide. Statistics, Release 8.2. SAS Institute Inc., Cary, NC.

Snyder, A. C., J. D. Schuh, T. N. Wegner, and J. R. Gebert. 1974 Passive immunization of the newborn dairy calf via fermented colostrum. J. Dairy Sci. 57:641. (Abstr.)
Staley, T. E., and L. J. Bush. 1985. Receptor mechanisms of the neonatal intestine and their relationship to Ig absorption and disease. J. Dairy Sci. 68:184-205.

Steele, M. L., W. B. McNab, C. Poppe, M. W. Griffiths, S. Chen, S. A. Degrandis, L. C. Fruhner, C. A. Larkin, J. A. Lynch, and J. A. Odumeru. 1997. Survey of Ontario bulk tank raw milk for food-borne pathogens. J. Food Prot. 60:1341-1346.

Streeter, R. N., G. F. Hoffsis, S. Bech-Nielsen, W. P. Shulaw, and D. M. Rings. 1995. Isolation of Mycobacterium paratuberculosis from colostrum and milk of subclinically infected cows. Am. J. Vet. Res. 56:1322-1324.

Sukumaran, M. V., and M. Subrahmanyam. 1980. Changes in the microflora of bovine colostrum during natural fermentation at room temperature for ten days. Kerala J. Vet. Sci. 11:42-47.

Thompson, T. L., and E. H. Marth. 1976. Changes in the microflora of bovine colostrum during natural fermentation. J. Milk Food Technol. 39:27-31.

Walz, P. H., T. P. Mullaney, J. A. Render, R. D. Walker, T. Mosser, and J. C. Baker. 1997. Otitis media in preweaned Holstein dairy calves in Michigan due to Mycoplasma bovis. J. Vet. Diagn. Invest. 9:250-254.

Wells, S. J., D. A. Dargatz, and S. L. Ott. 1996. Factors associated with mortality to 21 days of life in dairy heifers in the United States. Prev. Vet. Med. 29:9-19. 